\title{
Hitna stanja u neurologiji
}

\author{
D. Dujmović, M. Brkljačič́, N. Kučer, V. Matijatko, G. Jurkić i I. Kiš
}

\section{Sažetak}

Hitna su stanja po život opasna stanja koja zahtijevaju točnu i brzu intervenciju. Neprimjereno zbrinjavanje hitnog pacijenta može ostaviti trajne posljedice na njegovo zdravlje. Veliki se dio pacijenata u veterinarskoj maloj praksi prezentira $s$ različitim poremećajima neurološkog sustava što zbog složenosti dijagnostike i liječenja predstavlja veliki izazov za veterinare. Neurološki simptomi mogu biti posljedica primarne bolesti središnjeg ili perifernog živčanog sustava ili se mogu kod različitih sistemskih poremećaja javiti i sekundarno. Trijaža je postupak pomoću kojeg razvrstavamo stabilne od nestabilnih pacijenata, a daje i uvid u to koliko je njihovo zbrinjavanje hitno. Glavni cilj stabilizacije hitnih pacijenata je osigurati dostatnu količinu kisika mozgu, srcu i ostalim vitalnim organima. Detaljan se neurološki pregled pacijenata koji pokazuju neurološke simptome provodi nakon stabilizacije. Cilj neurološkog pregleda je ustanoviti je li

poremećaj neurološkog karaktera, odrediti lokalizaciju lezije i njezinu etiologiju te težinu stanja u kojemu se pacijent nalazi. Neurološki pregled obuhvaća: procjenu mentalnog statusa i ponašanja, procjenu stava i položaja tijela $\mathrm{u}$ prostoru, prisutnost abnormalnih pokreta, promatranje hoda, testiranje reakcija održavanja stava i položaja u prostoru, pregled kranijalnih živaca i spinalnih refleksa, palpaciju tijela i testiranje percepcije bola. U većini slučajeva možemo odrediti mjesto lezije što je u konačnici bitno za sastavljanje liste diferencijalnih dijagnoza i daljnjih dijagnostičkih i terapijskih planova. Prognoza pojedinih hitnih stanja $\mathrm{u}$ veterinarskoj neurologiji velikim dijelom ovisi i o lokalizaciji i etiologiji lezija.

Ključne riječi: hitna neurološka stanja, neurološki pregled pasa $i$ mačaka, veterinarska neurologija, traumatska ozljeda glave, status epileptikus

\section{Uvod}

Hitna su stanja po život opasna stanja te su brzina i način postupanja s pacijentom od iznimne važnosti. Hitni pacijenti mogu imati široki raspon simptoma tejebitnona vrijeme prepoznati kliničke znakove koji zahtijevaju brzu intervenciju s ciljem spašavanja života. Postupak pomoću kojeg razvrstavamo

nestabilne od stabilnih pacijenata naziva se trijaža. Razlikujemo telefonsku trijažu, trijažu u čekaonici te onu koju provodimo za vrijeme prvog pregleda životinje (Drobatz i sur., 2019.).

U veterinarskoj maloj praksi veliki se dio hitnih pacijenata prezentira $\mathrm{s}$ različitim poremećajima živčanog

Doris DUJMOVIĆ, dr. med. vet., Zagreb, Hrvatska; dr. sc. Mirna BRKLJAČIĆ* , dr. med. vet., izvanredna profesorica, (dopsni autor, e-mail: mbrkljacic@vef.unizg.hr), dr. sc. Nada KUČER, dr. med. vet., redovita profesorica, dr. sc. Vesna MATIJATKO, dr. med. vet., redovita profesorica, Gabrijela JURKIĆ, dr. med. vet., stručna suradnica, dr. sc. Ivana KIŠ, dr. med. vet., izvanredna profesorica, Veterinarski fakultet Sveučilišta u Zagrebu, Hrvatska 
sustava. Neurološki simptomi mogu biti posljedica primarne bolesti središnjeg ili perifernog živčanog sustava, ali se mogu kod različitih sistemskih poremećaja javiti i sekundarno. Epileptički napadaji, koma, pareza i paraliza su najčešća stanja koja mogu rezultirati dramatičnim posljedicama te zahtijevaju rano otkrivanje i hitnu terapijsku intervenciju (Kirby i Linklater, 2017.). Neprimjereno liječenje i postupci, u ranim fazama traume ili bolesti živčanog sustava, mogu ostaviti trajne posljedice na zdravlje životinje i smanjiti kvalitetu života. Zbog anatomske i fiziološke složenosti živčanog sustava, dijagnostika i liječenje neuroloških stanja često predstavljaju veliki izazov za veterinara.

\section{Pristup hitnom pacijentu s neurološkim simptomima}

Poimanje hitnog stanja može se uvelike razlikovati između veterinra i vlasnika životinje. Važno je znati da neka klinička stanja nisu odmah vidljiva ili nisu

Tabela 1. Trijaža pacijenata (prema Ruys i sur., 2012.)

\begin{tabular}{|c|c|c|c|c|}
\hline $\begin{array}{l}\text { Stupanj } \\
\text { hitnosti }\end{array}$ & I & II & III & IV \\
\hline Zbrinjavanje & Odmah & Unutar $15 \mathrm{~min}$ & Unutar $60 \mathrm{~min}$ & Unutar $120 \mathrm{~min}$ \\
\hline \multirow{8}{*}{ 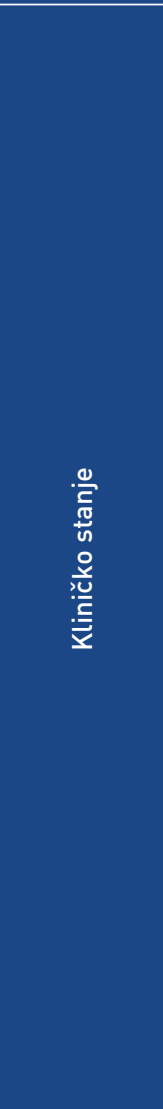 } & $\begin{array}{l}\text { - Respiratorni arest } \\
\text { - Opstrukcija dišnih } \\
\text { puteva }\end{array}$ & $\begin{array}{l}\text { - Akutni stridor } \\
\text { - Potkožni emfizem }\end{array}$ & $\begin{array}{l}\text { Umjereni } \\
\text { respiratorni } \\
\text { distres }\end{array}$ & \\
\hline & $\begin{array}{l}\text { - Dekompenzatorna } \\
\text { faza šoka } \\
\text { - Jako krvarenje }\end{array}$ & $\begin{array}{l}\text { - Blijede sluznice } \\
\text { bez znakova šoka } \\
\text { - Ascites }\end{array}$ & $\begin{array}{l}\text { - Perzistentno } \\
\text { blago } \\
\text { krvarenje }\end{array}$ & \\
\hline & $\begin{array}{l}\text { - Gubitak svijesti } \\
\text { - Napadaji }\end{array}$ & $\begin{array}{l}\text { - Poremećena } \\
\text { svijest } \\
\text { - Akutno } \\
\text { promijenjeno } \\
\text { ponašanje }\end{array}$ & $\begin{array}{l}\text { - Akutni } \\
\text { neurološki } \\
\text { deficit nižih } \\
\text { motoričkih } \\
\text { neurona }\end{array}$ & $\begin{array}{l}\text { - Nedavni } \\
\text { izolirani } \\
\text { napadaji }\end{array}$ \\
\hline & $\begin{array}{l}\text { - Akutno rastezanje } \\
\text { abdomena }\end{array}$ & $\begin{array}{l}\text { - Ingestija toksina } \\
\text { - Ingestija stranog } \\
\text { tijela uz povraćanje } \\
\text { - Opstrukcija uretre }\end{array}$ & $\begin{array}{l}\text { - Ingestija } \\
\text { stranog tijela } \\
\text { - Perzistentno } \\
\text { povraćanje } \\
\text { - Melena }\end{array}$ & $\begin{array}{l}\text { - Povraćanje } \\
\text { - Strangurija } \\
\text { - Tenezam }\end{array}$ \\
\hline & - Distocija & - Aktivni porođaj & $\begin{array}{l}\text { Krvarenje } \\
\text { iz vagine } \\
\text { gravidnih } \\
\text { životinja }\end{array}$ & \\
\hline & $\begin{array}{l}\text { - Suspektna } \\
\text { hipoglikemija }\end{array}$ & $\begin{array}{l}\text { - Dijabetička } \\
\text { ketoacidoza }\end{array}$ & & \\
\hline & $\begin{array}{l}\text { - } \mathrm{TT}>41^{\circ} \mathrm{C} \\
\text { - } \mathrm{TT}<36,7^{\circ} \mathrm{C}\end{array}$ & $\begin{array}{l}\text { - Dehidracija > } 8 \text { \% } \\
\text { - Petehije/ekhimoze }\end{array}$ & $\begin{array}{l}\text { - Dehidracija } \\
\text { 5-8\% } \\
\text { - Edem lica } \\
\text { - Izraženi } \\
\text { pruritus }\end{array}$ & $\begin{array}{l}\text { - Blago } \\
\text { povećanje TT }\end{array}$ \\
\hline & - Jake traume & $\begin{array}{l}\text { - Akutni gubitak vida } \\
\text { - Evisceracija } \\
\text { - Ugriz zmije }\end{array}$ & $\begin{array}{l}\text { - Otvorena } \\
\text { fraktura } \\
\text { - Veće ozljede } \\
\text { kože }\end{array}$ & - Oteklina \\
\hline
\end{tabular}

TT - tjelesna temperatura 
opasna po život $\mathrm{u}$ danom trenutku, ali s vremenom mogu postati. Pomoću trijaže prepoznat ćemo nalazi li se pacijent $u$ stanju opasnom po život, a ono zahtjeva trenutno zbrinjavanje.

Hitne pacijente zbrinjavamo odmah po dolasku, no ukoliko je istovremeno došlo više njih, trijažu provodimo $u$ čekaonici. Orijentacijski klinički pregled životinje je neophodan u prepoznavanju kritičnih stanja. Veterinarska je medicina za trijažu preuzela humane protokolepacijenti se nakon kratkog kliničkog pregleda razvrstavaju po stupnju hitnosti (Tabela 1.).

\section{Stabilizacija pacijenta}

Nakon što smo odredili koje je kliničko stanje potrebno zbrinuti bez odgađanja, provodimo trijažu na pojedinačnom pacijentu da bismo dobili sve važne informacije potrebne za uspješnu stabilizaciju. Potrebno je istovremeno prikupiti anamnestičke podatke od vlasnika, klinički pregledati pacijenta i napraviti najbitnije dijagnostičke pretrage. Radimo primarni pregled koji uključuje tzv. ABC pregled (engl. Airway, Breathing, Circulation) koji služi za prepoznavanje manje izraženih, ali potencijalno životno ugrožavajućih stanja.

U životinja koje su u kolapsu ili koje ne reagiraju ni na kakve podražaje, treba isključiti postojanje kardiopulmonalnog aresta (KPA) provodeći brzi $\mathrm{ABC}$ protokol $\mathrm{u}$ trajanju 10-15 sekundi. Ukoliko se pacijent nalazi $\mathrm{u}$ respiratornom arestu, tj. nisu prisutni spontani dišni pokreti, potrebno ga je intubirati i mehanički ventilirati (10-15 udisaja/min volumenom 10-15 mL/kg). U slučaju kardiopulmonalnog aresta potrebno je provesti kardiopulmonalnu reanimaciju (KPR) na način da se rade vanjske kompresije na srce (100-120/min) i mehaničko ventiliranje pacijenta $u$ omjeru 8-12:1 (Fletcher i sur., 2012.).

Daljnje zbrinjavanje pacijenta uključuje stabilizaciju stanja opasnih po život i provođenje ciljanih dijagnostičkih pretraga (Tabela 2.). Glavni cilj stabilizacije je osigurati dostatnu količinu kisika mozgu, srcu i ostalim vitalnim

Tabela 2. Stabilizacija stanja opasnih po život (prema Drobatz i sur., 2019.)

\begin{tabular}{|c|c|c|c|}
\hline \multicolumn{2}{|c|}{ Problem } & Hitno zbrinjavanje & Brza dijagnostika \\
\hline \multirow{3}{*}{$\begin{array}{l}\frac{\mathscr{o}}{c} \\
\frac{0}{0} \\
\frac{0}{0}\end{array}$} & Respiratorni arest & $\begin{array}{l}\text { Intubacija i mehanička } \\
\text { ventilacija, KPR }\end{array}$ & $\mathrm{EKG}, \mathrm{ETCO}_{2}$ \\
\hline & $\begin{array}{l}\text { Inspiracijska dispneja } \\
\text { Stenoza gornjih dišnih prohoda }\end{array}$ & $\begin{array}{l}\text { Uklanjanje stranog tijela, } \\
\text { intubacija, traheotomija }\end{array}$ & \\
\hline & Dispneja & $\mathrm{O}_{2}$, odmor, analgezija & Lokalizacija problema \\
\hline \multirow{2}{*}{ 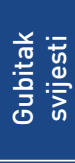 } & Koma & Intubacija, $\mathrm{O}_{2}$ & $\begin{array}{l}\text { Glukoza, } \mathrm{HCT} \text {, elektroliti, } \\
\text { acido-bazni status, } \mathrm{NH}_{3}\end{array}$ \\
\hline & Status epileptikus & Antiepileptička terapija & $\begin{array}{l}\text { Glukoza, } \mathrm{Ca}, \mathrm{Na}, \mathrm{NH}_{3} \\
\text { toksini u mokraći }\end{array}$ \\
\hline \multirow{3}{*}{$\begin{array}{l}\frac{0}{0} \\
\frac{\pi}{3} \\
\frac{1}{2} \\
\frac{1}{0}\end{array}$} & Dekompenzatorna faza šoka & $\begin{array}{l}\mathrm{O}_{2} \text {, IV kateter + kristaloidi/ } \\
\text { koloidi, analgezija }\end{array}$ & $\begin{array}{l}\text { HCT, ukupni proteini, } \\
\text { laktat, EKG }\end{array}$ \\
\hline & Arterijsko krvarenje & $\begin{array}{l}\text { Pritisak povojem, terapija šoka, } \\
\text { analgezija }\end{array}$ & $\begin{array}{l}\text { HCT, ukupni proteini, } \\
\text { laktat }\end{array}$ \\
\hline & Srčani arest & $\begin{array}{l}\text { KPR, intubacija, mehanička } \\
\text { ventilacija }\end{array}$ & $\mathrm{EKG}, \mathrm{ETCO}_{2}$ \\
\hline
\end{tabular}

$\mathrm{KPR}$ - kardiopulmonalna reanimacija, EKG - elektrokardiogram, $\mathrm{ETCO}_{2}$ - završni respiracijski volumen $\mathrm{CO}_{2}, \mathrm{HCT}$ - hematokrit, IV - intravenski 
organima, pri čemu slijedimo ABC redoslijedom; no treba uzeti u obzir težinu svakoga problema (npr. arterijsko krvarenje je često teži problem nego tahipneja). Nakon stabilizacije, radimo temeljiti klinički pregled pacijenta.

\section{Stabilizacija pacijenta s neurološkim simptomima}

Kada pacijent pokazuje očite neurološke simptome, ponajprije se provodi brzi $\mathrm{ABC}$ pregled da bismo isključili KPA; potom se provodi primarni pregled da bismo identificirali neizbježne dišne, kardiovaskularne i neurološke poremećaje (Drobatz i sur., 2019.). Budući da brojna stanja, tj. razni poremećaji (npr. hipoksija, vrućica, šok, tahi/ bradiaritmija, hipo/hiperglikemija, hipo/ hipernatrijemija, hipo/hiperkalemija, hiperosmolarnost, hipo/hiperkarbija itd.) mogu prouzročiti neurološke deficite temeljiti neurološki pregled, s ciljem određivanja lokalizacije, provodimo tek nakon korekcije navedenih poremećaja.

\section{Neurološki pregled}

Cilj neurološkog pregleda je najprije ustanoviti radi li se o poremećaju neurološkog porijekla, a potom i odrediti lokalizaciju neurološke lezije, njezin potencijalni uzrok te ozbiljnost stanja pacijenta. $\mathrm{Na}$ osnovu navedenih spoznaja, procjenjujemo prognozu (i moguće ishode) sa i bez liječenja. Neurološki pregled možemo podijeliti na pasivni (u kojem se koristimo isključivo inspekcijom) i aktivni dio (u kojem provodimo testove na različitim dijelovima živčanog sustava) (Platt i Garosi, 2012.).

\section{Mentalni status i ponašanje}

Ako je paciijent svjestan svoje okoline i odgovarajuće reagira na podražaje iz okoliša smatramo da je budan i da ima normalan stupanj svijesti.
Odstupanja od normalnog stupnja svijesti klasificiramo (od najblažeg do najjačeg) kao potištenost, stupor i komu. U pravilu, promijenjeni stupanj svijesti ukazuje na difuzno ili multifokalno oštećenje obje hemisfere velikog mozga i/ili ascedentnog retikularnog aktivacijskog sustava (Platt i Olby, 2012.). Promjene $u$ ponašanju zapažamo uspoređujući ponašanje pacijenta $s$ jedinkama iste vrste i dobi. Uobičajene promjene $u$ ponašanju životinje uključuju: dezorijentiranost, agresivnost, vokaliziranje i neodgovarajuće reagiranje na podražaje iz okoline koje mogu biti simptom oštećenja kore velikoga mozga (Dewey i Da Costa, 2016.).

\section{Stav i položaj tijela u prostoru}

Stav definiramo kao položaj očiju $i$ glave $u$ odnosu na tijelo životinje. Abnormalni stav se može očitovati kao nagnutost glave na lijevu ili desnu stranu, pri čemu oči i uši nisu u horizontalnoj ravnini, a najčešći uzrok takvog stava je jednostrani vestibularni sindrom. Uz nagnutost, javlja se i zaokrenutost glave na stranu pri čemu je podužna os glave zaokrenuta na podužnu os tijela, a može je pratiti i kruženje životinje $u$ istome smjeru. Takav stav može upućivati na ozljedu velikog mozga (Platt i Olby, 2012.).

Položaj tijela životinje definira se kao stav tijela u odnosu na silu težu. Široko postavljeni stav predstavlja abnormalni položaj životinje koja stoji pri čemu su ekstremiteti rašireni uz mogućnost hodanja životinje. Ovakav stav može ukazivati na obostrani vestibularni sindrom ili na oštećenje maloga mozga (Drobatz i sur., 2019.). U pacijenata koji leže na boku možemo uočiti mnoge abnormalne položaje. Decerebralnu rigidnost vidimo kao opistotonus i ekstenziju svih ekstremiteta uz nesvijesno stanje životinje, dok decerebelarna rigidnost predstavlja opistotonus $\mathrm{s}$ ekstenzijom prednjih i fleksijom stražnjih 
Tabela 3. Pojmovi kojima označavamo parezu/paralizu (prema Platt i Olby, 2012.)

\begin{tabular}{|l|l|l|}
\hline Pojam & Zahvaćeni ekstremitet/i & Uzrok \\
\hline Tetrapareza/plegija & Sva četiri & Oštećenje KM C1-T2 ili NMN \\
\hline Parapareza/plegija & Oba kaudalna & Oštećenje KM od T3 i kaudalnije \\
\hline Monopareza/plegija & Jedan & Oštećenje NMN \\
\hline Hemipareza/plegija & Dva ipsilateralno & $\begin{array}{l}\text { Kontralateralno oštećenje rostralnog } \\
\text { dijela srednjeg mozga ili ipsilaterano } \\
\text { oštećenje kaudalnog dijela srednjeg } \\
\text { mozga do T2 }\end{array}$ \\
\hline
\end{tabular}

ekstremiteta pri čemu je mentalni status životinje normalan. Oštećenja dijelova torakalne ili lumbalne kralježnične moždine dovode do ekstenzije prednjih ekstremiteta, uz paralizu stražnjih ekstremiteta, a navedeno nazivamo Schiff-Sherrington položajem (Dewey i Da Costa, 2016.). Kifozu, lordozu i skoliozu svrstavamo u abnormalne položaje kralježnice. Uzroci mogu biti kongenitalne malformacije, bolnost ili ozljeda kralježnice te slabost epaksijalne muskulature.

\section{Abnormalni pokreti}

Abnormalni pokreti su pokreti koji se javljaju bez kontrole volje te ih je bitno tijekom neurološkog pregleda uočiti i opisati. Mioklonus označava kratku, snažnu mišićnu kontrakciju grupe mišića nakon čega slijedi relaksacija istih. Brzi i ponavljajući ciklusi mioklonusa očituju se kao tremor (drhtanje) koje može zahvatiti cijelo tijelo ili samo jedan dio te se može klasificirati kao tremor u mirovanju ili kao tremor vezan uz neku voljnu radnju životinje (Platt i Garosi, 2012.). Miotonija je produljena, nepravilna kontrakcija mišića s odgođenom relaksacijom, a događa se nakon voljne kontrakcije mišićne skupine te može biti posljedica urođenih i stečenih poremećaja mišića. Potpuni gubitak tonusa muskulature cijelog tijela s očuvanjem svijesti nazivamo katapleksija. Napadaji obično traju nekoliko sekundi do nekoliko minuta i najčešće su izazvani uzbuđenjem životinje (npr. pri hranjenju) te se obično javljaju kod pacijenata s narkolepsijom (Platt i Olby, 2012.).

\section{Hod}

Hod životinje promatramo u prostoru gdje se životinja može slobodno kretati pri čemu je bitno da podloga po kojoj se kreće nije skliska. Odstupanja od normalnog hoda prepoznajemo kao šepanje, ataksiju, parezu i paralizu. Šepanje definiramo kao odstupanje kod kojeg se životinja manje oslanja na zahvaćeni ekstremitet i prebacuje težinu na kolateralni. Nemogućnost normalne koordinacije motoričke aktivnosti, koja nije posljedica mišićne slabosti, mišićnokoštanih oboljenja ili abnormalnih pokreta, nazivamo ataksija. Ona može biti proprioceptivna, cerebelarna i vestibularna. Parezu definiramo kao odstupanje $\mathrm{u}$ hodu kod kojeg dolazi do djelomičnog gubitka voljnih pokreta dok paraliza (plegija) označava potpuni gubitak istih (Tabela 3.). S obzirom na to koji je dio motoričkih neurona oštećen, poznajemo parezu viših motoričkih neurona (VMN) i parezu nižih motoričkih neurona (NMN). Neurološkim pregledom razlikujemo slabost prouzročenu oštećenjem jednog od dva navedena sustava (Tabela 4.).

\section{Reakcije održavanja stava i položaja u prostoru}

Životinje održavaju stav i položaj u prostoru pomoću istih neuroloških 
Tabela 4. Kliničko razlikovanje pareze VMN od pareze NMN (prema Platt i Garosi, 2012.)

\begin{tabular}{l|l|l|}
\hline Kriterij & Pareza VMN & Pareza NMN \\
\hline Hod & $\begin{array}{l}\text { Ukočen uz proprioceptivnu } \\
\text { ataksiju } \\
\text { Odgođen iskorak }\end{array}$ & \multicolumn{1}{|l}{ Skraćen korak } \\
\hline Motorička funkcija & Spastička pareza/paraliza & Flakcidna pareza/paraliza \\
\hline $\begin{array}{l}\text { Spinalni refleksi } \\
\text { Tonus mišića }\end{array}$ & Normalni do pojačani & Smanjeni do odsutni \\
\hline $\begin{array}{l}\text { Pasivna fleksija/ } \\
\text { ekstenzija uda }\end{array}$ & Normalan do blagi otpor & Smanjen otpor \\
\hline Atrofija mišića & Kasna i slaba & Smanjen otpor \\
\hline
\end{tabular}

VMN - viši motorički neuroni, NMN - niži motorički neuroni

putova koje koriste pri hodu, a to su propriocepcija i sustavi motoričkih neurona. Testiranje reakcija pomoći će nam $\mathrm{u}$ otkrivanju suptilnih deficita $\mathrm{i}$ razlika koje tijekom analize hoda nisu bile uočljive. Ovi testovi omogućuju i razlikovanje ortopedskog od neurološkog poremećaja (Dewey i Da Costa, 2016.). Uzlazni osjetilni putovi, uključujući cijeli proprioceptivni sustav, kao i silazni putovi, koji prolaze kroz leđnu moždinu do mišića-efektora, moraju biti neoštećeni. Oštećenja bilo kojeg dijela osjetilnih puteva dovest će do smanjene mogućnosti održavanja stava i položaja u prostoru (Drobatz i sur., 2019.).

- Pregled provodimo testiranjem od jednostavnijih do fizički zahtjevnijih reakcija (proprioceptivno pozicioniranje, "vožnja tački", pozicioniranje šapa na taktilne podražaje, skakutanje na pojedinačnim ekstremitetima). Čim u jednom testu dođe do odstupanja od fiziološkog, daljnje testiranje ne provodimo, jer bi ono moglo rezultirati ozljeđivanjem.

\section{Pregled kranijalnih (moždanih) živaca (KŽ)}

Poznato je 12 pari kranijalnih živaca koji polaze izravno iz mozga, a mogu biti samo osjetni, samo motorički ili mješoviti. Testovima provjeravamo funkciju, tj. dokazujemo disfunkciju jednog ili više živaca istovremeno što pomaže u otkrivanju lokalizacije problema (Tabela 5.). Da bismo mogli razlikovati centralne od perifernih lezija pregled $K \check{Z}$ provodimo uz testiranje propriocepcije i prosuđivanje mentalnog statusa (Drobatz i sur., 2019.).

\section{Pregled spinalnih refleksa i tonusa muskulature}

Pregledom spinalnih refleksa provjeravamo cjelovitost senzoričkih i motoričkih komponenti refleksnog luka te pomoću njega razlikujemo NMN oštećenja od oštećenja VMN. Testove radimo određenim redoslijedom, od najugodnijih do manje ugodnih, da bismo zadržali kooperaciju pacijenta. Testiranjem svakog refleksa testiramo cjelovitost pripadajućih živaca i određenog segmenta KM (Tabela 6).

\section{Palpacija}

Površinska palpacija pomaže u otkrivanju oteklina tkiva ili atrofije mišića, dok duboku palpaciju koristimo s ciljem utvrđivanja bolnosti nekog dijela tijela (Dewey i Da Costa, 2016.). Palpaciju dijelimo na: palpaciju glave, kralježnice i 
Tabela 5. Kranijalni živci, njihova funkcija i nalaz testova u slučaju oštećenja pojedinog živca (prema Dewey i Da Costa, 2016., Drobatz i sur., 2019.)

\begin{tabular}{|c|c|c|}
\hline Kranijalni živac & Funkcija/područje inervacije & Patološki nalaz testova \\
\hline $\begin{array}{l}\text { I } \\
\text { n. olfactorius }\end{array}$ & Njuh & Gubitak njuha \\
\hline $\begin{array}{l}\text { II } \\
\text { n. opticus }\end{array}$ & Vid & $\begin{array}{c}\text { Gubitak vida, odsutan pupilarni } \\
\text { refleks }\end{array}$ \\
\hline $\begin{array}{l}\text { III } \\
\text { n. oculomotorius }\end{array}$ & $\begin{array}{c}\text { Motorička grana za } m \text {. rectus dorsalis, } \\
\text { m. rectus ventralis, } m \text {. rectus medialis, } \\
\text { m. obliquus ventralis, } m \text {. levator } \\
\text { palpebrae superioris } \\
\text { Parasimpatička inervacija zjenice }\end{array}$ & $\begin{array}{c}\text { Abnormalni pokreti očne } \\
\text { jabučice, odsutan pupilarni } \\
\text { refleks }\end{array}$ \\
\hline $\begin{array}{l}\text { IV } \\
\text { n. trochlearis }\end{array}$ & Motorička grana za m. obliquus dorsalis & Strabizam \\
\hline $\begin{array}{l}\mathrm{V} \\
\text { n. trigeminus }\end{array}$ & $\begin{array}{l}\text { Osjet za veći dio lica } \\
\text { Motorička grana žvačnih mišića }\end{array}$ & $\begin{array}{c}\text { Odsutan palpebralni refleks } \\
\text { i osjet lica, atrofija žvačne } \\
\text { muskulature }\end{array}$ \\
\hline $\begin{array}{l}\text { VI } \\
\text { n. abducens }\end{array}$ & $\begin{array}{c}\text { Motorička grana za } m \text {. rectus lateralis i } \\
\qquad m \text {. retractor bulbi }\end{array}$ & $\begin{array}{l}\text { Odsutan kornealni refleks, } \\
\text { konvergentni strabizam }\end{array}$ \\
\hline $\begin{array}{l}\text { VII } \\
\text { n. facialis }\end{array}$ & $\begin{array}{l}\text { Motorička grana mimičkih mišića } \\
\text { Parasimpatička inervacija suznih i } \\
\text { slinskih žlijezda }\end{array}$ & $\begin{array}{l}\text { Odsutan palpebralni refleks } \\
\text { i odgovor na prijetnju, viseća } \\
\text { uška, usnica i vjeđa }\end{array}$ \\
\hline $\begin{array}{l}\text { VIII } \\
\text { n. vestibulocochlearis }\end{array}$ & Ravnoteža i sluh & $\begin{array}{l}\text { Nagnutost glave, abnormalni } \\
\text { nistagmus, strabizam, ataksija, } \\
\text { hodanje u krug, gubitak sluha }\end{array}$ \\
\hline $\begin{array}{c}\text { IX } \\
\text { n. glossopharingeus }\end{array}$ & $\begin{array}{c}\text { Okus } \\
\text { Osjetilna inervacija ždrijela i kaudalne } \\
\text { trećine jezika }\end{array}$ & Odsutan refleks gutanja \\
\hline $\begin{array}{l}\mathrm{X} \\
\text { n. vagus }\end{array}$ & $\begin{array}{c}\text { Parasimpatička inervacija visceralnih } \\
\text { organa } \\
\text { Osjetilna inervacija ždrijela } \\
\text { Motorička grana mišića ždrijela i } \\
\text { grkljana }\end{array}$ & $\begin{array}{l}\text { Odsutan refleks gutanja, } \\
\text { disfonija, laringealni stridor }\end{array}$ \\
\hline $\begin{array}{l}\text { XI } \\
\text { n. accessorius }\end{array}$ & $\begin{array}{c}\text { Motorička grana za } \\
\text { m. brachiocephalicus, } m \text {. } \\
\text { omotransversarius, } \\
\text { m. trapezius }\end{array}$ & Atrofija vratne muskulature \\
\hline $\begin{array}{c}\text { XII } \\
\text { n. hypoglossus }\end{array}$ & $\begin{array}{l}\text { Motorička grana vanjskih i unutarnjih } \\
\text { mišića jezika }\end{array}$ & $\begin{array}{c}\text { Nemogućnost zadržavanja } \\
\text { jezika u ustima, gubitak } \\
\text { motiliteta jezika, nemogućnost } \\
\text { uzimanja hrane i vode, atrofija } \\
\text { jezika }\end{array}$ \\
\hline
\end{tabular}

ekstremiteta. Glavu palpiramo da bismo otkrili bilo kakvu asimetriju, područje bolnosti ili prisutnost perzistentnih fontanela (Platt i Garosi, 2012.). Palpaciju kralježnice započinjemo nježnim pritiskom na paraspinalnu muskulaturu po- čevši od kranijalne torakalne regije pa sve do lumbosakralnog područja. Jačinu pritiska postupno povećavamo te obraćamo pažnju na moguće znakove bolnosti pri palpaciji. Ekstremitete palpiramo dok životinja stoji, a započinjemo površin- 
Tabela 6. Živci i segmenti KM testirani pojedinim refleksima (prema Platt i Olby, 2012.)

\begin{tabular}{|c|c|c|}
\hline Spinalni refleks & Živac & Segment KM \\
\hline Biceps & n. musculocutaneus & C6-C8 \\
\hline Triceps & n. radialis & C7-T2 \\
\hline Fleksorni prednje noge & $\begin{array}{c}\text { n. musculocutaneus, n. axillaris, } \\
\text { n. medianus, n. ulnaris, n. radialis }\end{array}$ & C6-T2 \\
\hline Patelarni & n. femoralis & L4-L6 \\
\hline Kranijalni tibijalni & n. ischiadicus & L6-L7 \\
\hline Fleksorni zadnje noge & n. ischiadicus & L6-S2 \\
\hline Perinealni & n. pudendus & S1-S3 + repni segmenti KM \\
\hline
\end{tabular}

KM - kralježnična moždina

skom palpacijom paralelnih udova da bismo usporedili simetričnost. Palpacija mišićnog sustava može pomoći u otkrivanju atrofija koje mogu biti posljedica oštećenja dijela KM, perifernog živca koji inervira određeni mišić ili ortopedske bolesti (Platt i Garosi, 2012.). Kod palpacije zglobova obraćamo pažnju na prisutnost oteklina, temperiranosti i/ili boli te provjeravamo stabilnost samog zgloba.

\section{Testiranje percepcije bola - nocicepcija}

Nocicepcija se definira kao svjesno doživljavanje bolnih podražaja i dio je obrambenog mehanizma. Da bi životinja doživjela osjet bola, bolni podražaj mora doći od mjesta lezije, preko perifernih živaca i KM, do centra za bol u talamusu; potom se podražaj iz talamusa prenosi do kore velikoga mozga i životinja tada svjesno doživljava bol (Platt i Olby, 2012.). Nocicepcija ima veliko dijagnostičko značenje u slučaju oštećenja KM ili perifernih živaca. Testiranje provodimo štipanjem pacijenta prstima ili peanom. Okretanje glave, vokalizacija ili pokušaj ugriza ukazuje na svjesno percipiranje boli. Ukoliko navedeni znaci izostanu, možemo zaključiti da pacijent nema osjet površinske boli te testiranje ponavljamo jačim pritiskom peana da bismo izazvali duboku bol (Dewey i Da Costa, 2016.).

\section{Lokalizacija neurološke lezije i lista diferencijalnih dijagnoza}

U trenutku kada smo identificirali sve neurološke abnormalnosti, možemo odrediti mjesto lezije što je u konačnici bitno za sastavljanje liste diferencijalnih dijagnoza i daljnjih dijagnostičkih i terapijskih planova (Tabela 7.). Važno je upamtiti da, ovisno o težini lezije, pacijent možda neće pokazati sve abnormalnosti povezane s određenom neuroanatomskom lokalizacijom. Kod sastavljanja liste diferencijalnih dijagnoza u obzir treba uzeti anamnezu i lokalizaciju neurološke lezije te osnovne podatke o pacijentu jer brojni neurološki problemi imaju dobnu, vrsnu ili pasminsku predispoziciju (Dewey i Da Costa, 2016.).

$\mathrm{U}$ neurologiji tijekom vremena što ovisi o patofiziološkim procesima koji dovodi do pojave bolesti postoje jasno definirani uzorci razvoja kliničkih simptoma bolesti (Platt i Olby, 2012.). Takvi uzroci mogu biti mnogobrojni, stoga koristimo akronim VITAMIN D da bismo ih lakše zapamtili:

- Vaskularno

- Infekcijski, Inflamatorno

- Trauma

- Anomalija

- Metabolički 


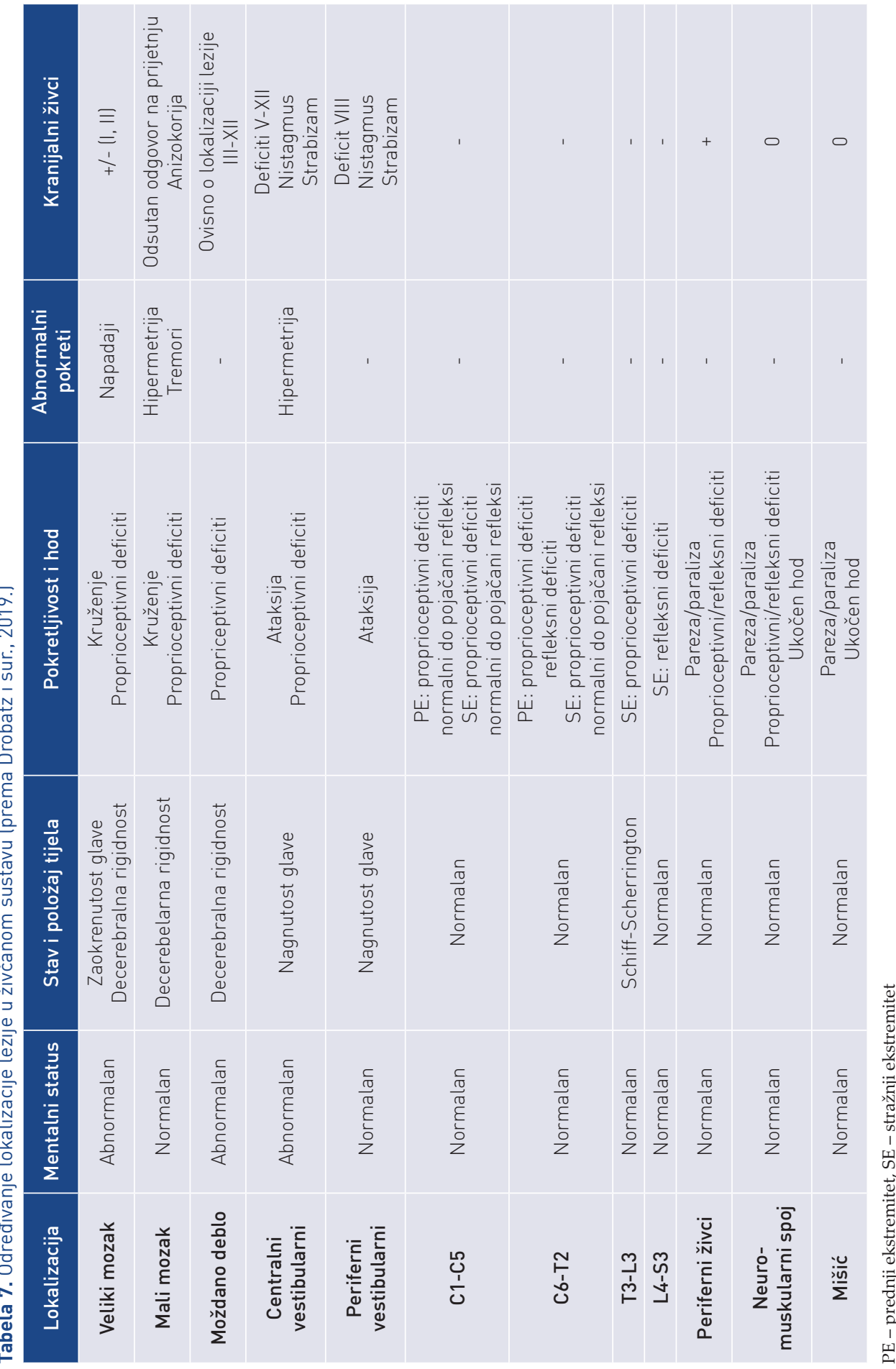


- Idiopatski (jatrogeno)

- Neoplazija, Nutritivno

- Degenerativno

Svaki od ovih procesa ima karakterističan početak i progresiju, kao i eventualnu regresiju unutar pojedinih anatomskih djelova živčanog sustava. Detaljna anamneza, temeljit klinički pregled i kvalitetan dijagnostički plan pomažu u razlikovanju simptoma koji su posljedica primarne bolesti neurološkog sustava od onih koji se kao posljedica različitih sistemskih poremećaja javljaju sekundarno.

\section{Traumatska ozljeda glave}

Trauma se glave javlja u $35 \%$ veterinarskih pacijenata koji su doživjeli tupu traumu i općenito može prouzročiti visoki morbiditet i mortalitet $\mathrm{u}$ veterinarskoj medicini (Drobatz i sur., 2019.). Radi se o tjelesnoj ozljedi moždanog tkiva koja trajno ili privremeno oštećuje moždanu funkciju, a do uginuća obično dolazi zbog progresivnog povećanja intrakranijalnog tlaka. Ozljede glave dijelimo na: primarne i sekundarne. Primarne ozljede nastaju uslijed traume i izravni su rezultat djelovanja sile na organizam. One uključuju: epiduralne i subduralne hematome, subarahnoidalno i intracerebralno krvarenje, kortikalne kontuzije i hematome te difuznu ozljedu aksona. Takva stanja unutar mozga pokreću brojne biokemijske procese što će rezultirati sekundarnom ozljedom mozga te daljnjim pogoršanjem kliničkog stanja životinje (Dewey i Da Costa, 2016.). $\mathrm{Za}$ uspješnu stabilizaciju pacijenta $\mathrm{s}$ traumatskom ozljedom glave presudno je prepoznati kliničke znakove povećanja intrakranijalnog tlaka ili deficita neurološkog sustava.

- Znaci traume:

- epistaksa

- krvarenje iz zvukovoda
- hifema

- fraktura lubanje i/ili zuba

- Neurološki deficiti (McMichael, 2014.):

- promijenjen stupanj svijesti

- patološki nistagmus

- opistotonus

- anizokorija

- deficiti KŹ

- generalizirani/fokalni napadaji

- Cushingov refleks

- decerebralna i decerebelarna rigidnost

Cushingov refleks nastaje kao odgovor na povišenje IKT-a, a karakterizira ga pojava hipertenzije, bradikardije te nepravilnog disanja (Sande i West, 2010.).

\section{Stabilizacija}

Tijekom trijaže pacijenta usredotočit ćemo se primarno na $\mathrm{ABC}$ protokol i stabilizaciju respiratornog i kardiovaskularnog sustava.

- Oksigenacija i ventilacija

Izbjegavati korištenje nosnog katetera kod oksigenacije jer može potaknuti kihanje i pri tome povećanje IKT-a. Hipoventilacija je indikacija za intubiranje i mehaničku ventilaciju pacijenta (Hopper i Powell, 2013.).

- Otvoriti venski put (izbjegavati $v$. jugularis jer kompresija vene može povećati IKT) i uzeti uzorke krvi

- Izmjeriti HCT, ukupne proteine, glukozu, laktat, elektrolite

- Pratiti vitalne znakove (EKG, pulsni oksimetar)

- Tretirati hipoperfuziju/hipovolemiju

- Podignuti glavu za $15-30^{\circ}$ da bi se olakšala venska drenaža i pritom smanjio IKT

- Terapija tekućinama

Davati IV izotonične otopine kristaloida (bolusi koloida po potrebi). Hipertonične otopine imaju nekoliko pred- 
nosti: brzi porast intravaskularnog volumena, povećanje minutnog volumena, poboljšanje cerebralnog protoka krvi, smanjenje IKT-a (Cooper i sur., 2004.), a možemo ih koristiti i u euhidriranih pacijenata bez značajnih poremećaja natrija. U slučaju anemije i niskog HCT-a uputno je napraviti transfuziju pune krvi (Dewey i Da Costa, 2016.).

- Procjena neurološkog stanja pacijenta Neurološku procjenu radimo nakon primarne stabilizacije pacijenta. Koristimo Modificiranu Glasgow Koma Skalu (MGCS) kojom procjenjujemo motoričku aktivnost, razinu svijesti i reflekse produljene moždine te objektivno bodujemo stanje pacijenta, a istovremeno procijenjujemo uspjeh samog liječenja (Tabela 8.). Ponavljanje neurološke procjene preporučuje se svakih 3060 min nakon inicijalnog pregleda pacijenta i nakon primjenjene terapije (Difazio i Fletcher, 2013.). Svaka kategorija se zasebno ocjenjuje te se na kraju bodovi zbrajaju da bi smo ustanovili postojanje i težina disfunkcije SŽS-a. Ukupni zbroj od 3-8 bodova označava tešku disfunkciju SŽS-a, 9-14 bodova disfunkciju srednjeg stupnja, a 15-18 disfunkciju blažeg stupnja ili odsutnost disfunkcije (Hall i sur., 2014.). MGCS bodovi nakon traumatske ozljede glave koreliraju s vjerojatnošću

Tabela 8. Modificirana Glasgow Koma Skala (prema Difazio i Fletcher, 2013.)

\begin{tabular}{|c|c|}
\hline Modificirana Glasgow Koma Skala & Bodovi \\
\hline \multicolumn{2}{|l|}{ Razina svijesti } \\
\hline Normalna razina svijesti, reagiranje na okolinu & 6 \\
\hline Depresija/delirij, nenormalno reagiranje na okolinu & 5 \\
\hline Stupor/semikoma, reagiranje na vizualni podražaj & 4 \\
\hline Stupor/semikoma, reagiranje samo na zvučni podražaj & 3 \\
\hline Stupor/semikoma, reagiranje samo na bolni podražaj & 2 \\
\hline Koma, ne reagiranje na ponovljeni bolni podražaj & 1 \\
\hline \multicolumn{2}{|l|}{ Motorička aktivnost } \\
\hline Normalan hod, normalni spinalni refleksi & 6 \\
\hline Hemipareza, tetrapareza ili decerebralna aktivnost & 5 \\
\hline Bočni položaj; povremena ekstenzorna rigidnost & 4 \\
\hline Bočni položaj; stalna ekstenzorna rigidnost & 3 \\
\hline Bočni položaj; stalna ekstenzorna rigidnost sa opistotonusom & 2 \\
\hline Bočni položaj; hipotonija mišića, slabi/odsutni spinalni refleksi & 1 \\
\hline \multicolumn{2}{|l|}{ Refleksi produljene moždine } \\
\hline Normalni pupilarni i okulocefalički refleks & 6 \\
\hline Usporeni pupilarni refleks; normalni/smanjeni okulocefalički refleks & 5 \\
\hline Bilateralna neresponsivna mioza; normalan/smanjen okulocefalički refleks & 4 \\
\hline Točkaste zjenice; smanjen/odsutan okulocefalički refleks & 3 \\
\hline Unilatealna neresponsivna midrijaza; smanjen/odsutan okulocefalički refleks & 2 \\
\hline Bilateralna neresponsivna midrijaza; smanjen/odsutan okulocefalički refleks & 1 \\
\hline
\end{tabular}


preživljavanja pacijenta $\mathrm{u}$ prvih $48 \mathrm{~h}$ (Platt i sur., 2001.).

- Analgezija

Analgetike koristimo nakon neurološke procjene; time izbjegavamo povišenje IKT-a prouzročeno boli i uznemirenošću (Roberts i sur., 2011.). Preporuča se uporaba opioida zbog lakoće poništavanja djelovanja antagonistima (Hansen, 2015.).

- Diuretici

Preporuča se korištenje mannitola u pacijenata s povišenim IKT-om u dozi 0,5-1,5 g/kg IV kroz 15 min. Uvijek se daje uz tekućinsku terapiju da bismo izbjegli hipovolemiju (Dewey i Da Costa, 2016.).

- Kortikosteroidi nisu preporučeni u pacijenata s traumatskom ozljedom glave

- Antikonvulzivnu terapiju dajemo ukoliko se jave napadaji (Tabela 9.)

\section{Prognoza}

Oporavak pacijenta od traumatske ozljede mozga ovisi o težini i uzroku ozljede, mjestu nastanka lezija te načinu i djelotvornosti provedene terapije (Difazio i Fletcher, 2013.). Pacijenti s oštećenjem velikog ili malog mozga imaju veće šanse za oporavak od pacijenata s oštećenjem moždanog debla (De Lahunta i sur., 2008.). Napredna slikovna dijagnostika (CT, MR) i MGCS su dijagnostički postupci koji nam pomažu u donošenju prognoze. Smatra se da pacijenti kojima je bila potrebna intubacija i koji su pokazivali znakove povećanja IKT-a imaju manju vjerojatnost preživljavanja (Sharma i Holowaychuk, 2015.). Mnogi se pacijenti mogu oporaviti od primarne ozljede uzrokovane traumom glave ukoliko možemo uspješno kontrolirati sekundarnu ozljedu mozga (Platt i Olby, 2012.).

\section{Status epileptikus}

Epileptički napadaj se definira kao abnormalna, prekomjerna i hipersinkrona električna aktivnost neurona unutar kore mozga koja rezultira promjenom stupnja svijesti i senzorija, pojavom konvulzija ili nevoljnih kretnji. Klinički gledano, takvi napadaji se ponavljaju u kratkom vremenskom razmaku s prolaznim narušenjem funkcije mozga (Platt i Garosi, 2012.). Uzroke napadaja u dijagnostičkom smislu dijelimo na: metaboličke, strukturne i idiopatske. Metabolička/reaktivna epilepsija se javlja kao odgovor na metaboličku bolest ili izloženost toksinima (npr. hepatička encefalopatija, hipoglikemija, hipokalcemija, trovanje etilen glikolom) dok se strukturna/simptomatska epilepsija javlja zbog intrakranijalnih patoloških stanja (npr. hidrocefalus, neoplazma, trauma, meningoencefalitis, ishemija) (Drobatz i sur., 2019.).

Status epileptikus (SE) predstavlja napadaj koji traje dulje od 5 min ili više napadaja između kojih pacijent ne može vratiti normalan stupanj svijesti. Ukoliko napadaj traje dulje od 30 min, može doći do sistemskih poremećaja (hipoksija, hipertermija, šok, metabolička acidoza, akutno zatajenje bubrega) te posljedično trajnog oštećenja mozga i smrti (Blades Golubovic i Rossmeisl Jr. 2017.a). Točan uzrok pojave SE nije otkriven, može se javiti kod epilepsije bilo koje etiologije. Poznato je da otprilike $60 \%$ pacijenata s idiopatskom epilepsijom zbog razvoja SE $\mathrm{u}$ određenom trenutku zahtjeva hitno zbrinjavanje (Monteiro i sur., 2012.).

- Promjena stupnja svijesti, konvulzije, nevoljne kretnje, neurološki deficiti Pacijent najčešće dolazi u fazi samog napadaja ili u postiktalnoj fazi (razdoblje od završetka napadaja do potpunog oporavka; može trajati minutama ili satima nakon napadaja) kada je neurološkim pregledom moguće uočiti neurološke deficite (McMichael, 2014.). Nekonvulzivni SE u veterinar- 
skoj medicini nije dokumentiran, no nerijetka je pojava $\mathrm{u}$ humanoj medicini (Platt i Garosi, 2012.).

\section{Stabilizacija}

Stabilizacija pacijenata u SE uvijek započinje $\mathrm{ABC}$ protokolom.

- Oksigenacija, ventilacija

- Izmjeriti vrijednosti trijasa, otvoriti venski put (izbjegavati $v$. jugularis jer kompresija vene može povećati intrakranijalni tlak (IKT)) i uzeti uzorke krvi; izmjeriti HCT, ukupne proteine, glukozu, elektrolite, a ako je moguće i acidobazni status

Potrebno je isključiti (McMichael, 2014.):

- hipoglikemiju

- hipokalcemiju

- anemiju/policitemiju

- hipertermiju

- trovanja

- neoplazme

- Antikonvulzivna terapija

$S$ obzirom na nalaze provedenih dijagnostičkih pretraga, primjenjuje se terapija usmjerena na uklanjanje utvrđenih poremećaja te antikonvulzivna terapija (Tabela 9.). Cilj terapije je što prije zaustaviti napadaj da bi se izbjegle posljedice dugačkog iktalnog razdoblja: povećani IKT, nepovrat- no oštećenje neurona, edem mozga, hipoksija tkiva, diseminirana intravaskularna koagulopatija (Drobatz i sur., 2019.).

Potrebno je uvijek biti spreman na intubaciju i mehaničku ventilaciju životinje, jer može doći do depresije disanja. Napadaji se obično nakon primjene bolusa vrate pa je poželjno davati terapiju u trajnoj infuziji (engl. CRI - constant rate infusion) (Dewey i Da Costa, 2016.):

- diazepam 0,5-2 $\mathrm{mg} / \mathrm{kg} / \mathrm{sat} u$ otopinama s glukozom

- propofol $6 \mathrm{mg} / \mathrm{kg} / \mathrm{sat}$

\section{Prognoza}

Prognoza SE uvelike ovisi o etiologiji samog napadaja. Ona je, ukoliko ne možemo stabilizirati pacijentovo stanje, tj. zaustaviti napadaje, nepovoljna. Neki pacijenti trebaju jaku sedaciju 24-72 h i potom se uspiju oporaviti. Otprilike $60 \%$ pasa zaprimljenih u SE se oporavi (Dewey i Da Costa, 2016.).

\section{Zaključak}

Neurološka stanja u hitnoj veterinarskoj medicini su česta pojava stoga je od velike važnosti poznavanje protokola stabilizacije pacijenta, a

Tabela 9. Stabilizacija SE antikonvulzivnom terapijom (prema Dewey i Da Costa, 2016., Blades Golubovic i Rossmeisl Jr. 2017.b]

\begin{tabular}{|c|c|c|c|c|}
\hline & & Pas & Mačka & \\
\hline \multirow{2}{*}{1} & Diazepam & $\begin{array}{l}\text { 0,5-1 } \mathrm{mg} / \mathrm{kg} \text { IV, } \\
\text { rektalno }\end{array}$ & $\begin{array}{l}0,5-1 \mathrm{mg} / \mathrm{kg} \text { IV } \\
\text { rektalno }\end{array}$ & \multirow{2}{*}{$\begin{array}{l}\text { Učinak kroz } 5 \text { min } \\
\text { Ponavljati max } 3 x\end{array}$} \\
\hline & Midazolam & $0,07-0,22 \mathrm{mg} / \mathrm{kg}$ IV, IM & $0,07-0,22 \mathrm{mg} / \mathrm{kg}$ IV, IM & \\
\hline \multirow{3}{*}{2} & Fenobarbital & $\begin{array}{c}4-6 \mathrm{mg} / \mathrm{kg} \mathrm{IV} \\
\text { Max } 24 \mathrm{mg} / \mathrm{kg} \mathrm{u} 24 \mathrm{~h}\end{array}$ & $\begin{array}{l}1-1,25 \mathrm{mg} / \mathrm{kg} \mathrm{IV} \\
\text { Max } 20 \mathrm{mg} / \mathrm{kg} \text { IV }\end{array}$ & $\begin{array}{l}\text { Učinak kroz 15-20 min } \\
\text { Ponavljati svakih } 6 \text { h }\end{array}$ \\
\hline & Propofol & $2-8 \mathrm{mg} / \mathrm{kg}$ IV & $2-8 \mathrm{mg} / \mathrm{kg} \mathrm{IV}$ & Brz učinak \\
\hline & Ketamin & $5 \mathrm{mg} / \mathrm{kg}$ IV & $5 \mathrm{mg} / \mathrm{kg}$ IV & Brz učinak \\
\hline 3 & Izofluran & & & \\
\hline
\end{tabular}

Max-maksimalno 
potom i sastavljanje liste diferencijalnih dijagnoza, da bismo pružili adekvatno zbrinjavanje. U svakog hitnog pacijenta pa tako i onog koji pokazuje neurološke simptome, stabilizacija započinje ABC protokolom kako bi osigurali dostatnu perfuziju živčanog sustava. Uz to, neizbježno je otvaranje venskog puta potrebnog za uzimanje uzoraka krvi i davanje tekućinske terapije. Daljnja stabilizacija ovisi o nalazu krvnih pretraga, stanju pacijenta i kliničkom pregledu. Ukoliko pacijent pokazuje neurološke simptome, nakon stabilizacije provodimo neurološki pregled, tj. procjenu neurološkog statusa. Prognoza pojedinih stanja uvelike ovisi i o etiologiji i lokalizaciji lezija, ali i o stručnosti i pravovremenoj intervenciji veterinara.

\section{Literatura}

1. BLADES GOLUBOVIC, S. and J. H. ROSSMEISL JR. (2017a): Status Epilepticus in Dogs and Cats, part 1: Etiopathogenesis, Epidemiology and Diagnosis. J. Vet. Emerg. Crit. Care 27, 278-287. 10.1111/vec. 12605

2. BLADES GOLUBOVIC, S. and J. H. ROSSMEISL JR. (2017b): Status Epilepticus in Dogs and Cats, part 2: Treatment, Monitoring and Prognosis. J. Vet. Emerg. Crit. Care 27, 288-300. 10.1111/ vec. 12604

3. COOPER, D. J., P. S. MYLES, F. T. MCDERMOTT, L. J. MURRAY, J. LAIDLAW, G. COOPER, A. B. TREMAYNE, S. S. BERNARD and J. PONSFORD (2004): Prehospital Hypertonic Saline Resuscitation of Patients With Hypotension and Severe Traumatic Brain Injury. J. Am. Med. Assoc. 291, 1350-1357. 10.1001/jama.291.11.1350

4. DE LAHUNTA, A., E. GLASS and M. KENT (2008): Neuroanatomy and Clinical Neurology, $3^{\text {rd }}$ ed., Elsevier, St. Louis. Pp. 476-486.

5. DEWEY, C. W. and R. C. DA COSTA (2016): Practical Guide to Canine and Feline Neurology, $3^{\text {rd }}$ ed., John Wiley \& Sons Inc., Ames. Pp. 1-269.

6. DIFAZIO, J. and D. J. FLETCHER (2013): Updates in the Management of the Small Animal Patient with Neurologic Trauma. Vet. Clin. North Am. Small Anim. Pract. 43, 915-940. 10.1016/j. cvsm.2013.03.002

7. DROBATZ, K. J., K. HOPPER, E. ROZANSKI and D. C. SILVERSTEIN (2019): Textbook of Small Animal Emergency Medicine, Volume 1, John Wiley \& Sons Inc., Hoboken. 1-131.
8. FLETCHER, D. J., M. BOLLER, B. M. BRAINARD, S. C. HASKINS, K. HOPPER, M. A. MCMICHAEL, E. A. ROZANSKI, J. E. RUSH and S. D. SMARICK (2012): Recover Evidence and Knowledge Gap Analysis on Veterinary CPR. Part 7: Clinical Guidelines. J. Vet. Emerg. Crit. Care Suppl 1., 102131. 10.1111/j.1476-4431.2012.00757.x

9. HALL, K. E., M. K. HOLOWAYCHUK, C. R. SHARP and E. REINEKE (2014): Multicenter Prospective Evaluation of Dogs with Trauma. J. Am. Vet. Med. Assoc. 244, 300-308. 10.2460/ javma.244.3.300

10. HANSEN, B. (2000): Acute Pain Management. Vet. Clin. North Am. Small Anim. Pract. 30, 899-916. 10.1016/s0195-5616(08)70014-7

11. HOPPER, K. and L. L. POWELL (2013): Basics od Mechanical Ventilation for Dogs and Cats. Vet. Clin. North Am. Small Anim. Pract. 43, 955-969. 10.1016/j. cvsm.2013.03.009

12. KIRBY, R. and A. LINKLATER (2017): Monitoring and Intervention for Critically III Small Animal, The Rule of 20, John Wiley \& Sons, Inc., Oxford. Pp. 207-208.

13. MCMICHAEL, M. (2014): Handbook of Canine and Feline Emergency Protocols, John Wiley \& Sons Inc., Ames. Pp. 123-128.

14. MONTEIRO, R., V. ADAMS, D. KEYS and S. R. PLATT (2012): Canine Idiopathic Epilepsy: Prevalence and Risk Factors and Outcome Associated with Cluster Seizures and Status Epilepticus. J. Small Anim. Pract. 53, 526-530. 10.1111/j.1748-5827.2012.01251.x

15. PLATT, S. R. and L. S. GAROSI (2012): Small Animal Neurological Emergencies, Manson Publishing Ltd. London. Pp. 1-417.

16. PLATT, S. R. and N. J. OLBY (2012): BSAVA Manual od Canine and Feline Neurology, $4^{\text {th }}$ ed., British Small Animal Veterinary Association. England. Pp. 1-388.

17. ROBERTS, D. J., R. I. HALL, A. H. KRAMER, H. L. ROBERTSON, C. N. GALLAGHER and D. A. ZYGUN (2011): Sedation for Critically Ill Adults with Severe Traumatic Brain Injury: A Sistematic Review od Randomized Controlled Trials. Crit. Care Med. 39, 2743-2751. 10.1097/ CCM.0b013e318228236f

18. RUYS, L. J., M. GUNNING, E. TESKE, J. H. ROBBEN and N. E. SIGRIST (2012): Evaluation of a Veterinary Triage List Modified form a Human Five-Point Triage System in 485 Dogs and Cats. J. Vet. Emerg. Crit. Care 22, 303-312. 10.1111/j.14764431.2012.00736.x

19. SANDE, A. and C. WEST (2010): Traumatic Brain Injury: A Review od Pathophysiology and Management. J. Vet. Emerg. Crit. Care 20, 177-190. 10.1111/j.1476-4431.2010.00527.x

20. SHARMA, D. and M. K. HOLOWAYCHUK (2015): Retrospective Evaluation od Prognostic Indicators in Dogs with Heat Trauma: 72 Cases (JanuaryMarch 2011). J. Vet. Emerg. Crit. Care 25, 631-639. $10.1111 /$ vec. 12328 


\section{Emergencies in neurology}

Doris DUJMOVIĆ, DVM, Zagreb, Croatia; Mirna BRKLJAČIĆ, DVM, PhD, Associate Professor, Nada KUČER, DVM, PhD, Full Professor, Vesna MATIJATKO, DVM, PhD, Full Professor, Gabrijela JURKIĆ, DVM, Expert Associate, Ivana KIŠ, DVM, PhD, Associate Professor, Faculty of Veterinary Medicine University of Zagreb, Croatia

Emergencies are life-threatening conditions that require accurate and prompt intervention. Inadequate medical care in the early stages of patient stabilization can leave lasting consequences on health. A large proportion of patients in veterinary small practice also present various neurological disorders, which can pose a challenge for the veterinarian due to the complexity of diagnosis and treatment. Neurological symptoms may arise due to primary disease of the central or peripheral nervous system, or secondarily as a result of systemic disorders. Triage is a procedure that allows for differentiation between stable and unstable patients and helps clinician decide which condition is the most serious and should be dealt with first. The main goal in stabilizing emergency patients is to ensure sufficient oxygen supply to the brain, heart and other vital organs. Once stabilised, patients with neurological symptoms should receive a detailed neurological examination. The aim of the neurological examination is to determine whether the nature of the disorder, location of the lesion and its aetiology, and the severity of the patient's condition. The neurological exam includes evaluation of posture and body position at rest, identification of abnormal movements, evaluation of gait, postural reaction testing, cranial nerve and spinal reflex examination, palpation and nociceptive testing. In most cases, the location of the lesion can be determined, and this is ultimately essential for compiling a list of differential diagnoses and for defining further diagnostic and treatment plans. The prognosis of individual emergencies in veterinary neurology largely depends on the location and aetiology of the lesion.

Key words: neurological emergencies; neurological examination of dogs and cats; veterinary neurology; traumatic brain injury, status epilepticus 